\title{
Te Kete Tuawhā, Te Kete Aroiti - The Fourth Basket
}

\section{Introduction}

Tradition tells us that there were three baskets of knowledge. For those unfamiliar with our traditions and culture let me state here the names of those baskets and their contents:

te kete tuauri: the basket of peace, love and all things good

te kete tuatea: the basket of warfare, black magic,

agriculture, tree or wood work, stone work and earth

works

te kete aronui: the basket of incantations, literature,

philosophy and all forms of ritual employed by man

These three baskets of knowledge were obtained for mankind by the god Tāne, known primarily as the god of the forests and all that dwells within them. Tāne, of course, has other claims to fame, principally the enforced separation of his parents Rangi, the sky father, and Papa-tū-ā-nuku, the earth mother, thereby allowing light into the world, and the creation of the first woman, Hine-ahu-one, thereby providing the female element. Tradition states that Rangi and Papa had seventy sons, the youngest of whom was Rūaumoko, the god of earthquakes and volcanoes. He was still suckling at his mother's breast when Tāne separated their parents, an act which Rūaumoko has not forgiven. He manifests his anger and rage every once in a while by causing the odd earthquake or volcanic eruption.

To return to the god, Tāne. To acquire the baskets of knowledge, Tāne had to ascend to the twelfth heaven, to Te

Dr Tìmoti Kāretu established the Department of Māori at The University of Waikato as Head of Department and then Professor before becoming the first Māori Language Commissioner. He is currently the Chairperson of the Te Kōhanga Reo National Trust 
Toi-o-ngā-rangi, and there be ushered into the presence of the Supreme God, of Io-matua-kore himself, to make his request. The request was granted and hence the knowledge we now have in our possession and at our disposal.

The sceptics and the cynics would probably dismiss this as the mere ravings of a quaint Polynesian people inhabiting this country of Aotearoa somewhere in the South Pacific. However, credulity need not be stretched too far if one were to consider that Tāne had to reconnoitre and negotiate eleven other heavens before ascending to the twelfth and there receive the knowledge he sought.

At each of the heavens there were rituals and tests, both mental and physical, to which he had to submit, not least of all the chicanery and the unscrupulousness of his older brother, Whiro, who firmly believed that primogeniture gave him prior rights to the baskets of knowledge. Whiro, in tradition, epitomises all that is evil and antisocial.

However, as Tāne continued to outmanoeuvre his older brother and to satisfy the requirements demanded of him, he continued to ascend, eventually arriving at the twelfth heaven. Allegorically and metaphorically, one can see that to acquire any knowledge sacrifices have to be made and tests of endurance successfully negotiated. All of us who have ever sought knowledge know this to be true!

For anyone with a teaching background these would appear to be some form of syllabus to master if one were to become knowledgeable, each kete and its contents being discrete and therefore distinct fields of knowledge to master.

While, in traditional Māori society, knowledge, in all its forms, particularly at the advanced levels, was the exclusive domain of high-born males, many of this class were unable to meet the very stringent demands placed on them, hence the knowledge was confined to that very select few who were able to make it to the 'twelfth heaven'. So all the baskets of knowledge, as alluded to by my ancestors, still have their place.

Let us now return to the title of this paper, te kete tuawhā, te kete aroiti. It seemed to me that I needed a fourth basket because the sentiments I now wish to express are not readily catered for by the three baskets already mentioned. I doubt that it was an oversight on the part of my ancestors, for they were not able to envisage the sort of world their descendants would inherit and the trials and tribulations they would be forced to face and endure. 
Te kete aronui is the kete that interests me the most as it is the kete of ritual, of literature, the kete of the humanities, I would like to think. It is the kete of the intellectual and the philosopher and I am prepared to state here that the poets and philosophers of the Māori world were the equal of poets and philosophers anywhere. Myopia on my part? I think not. The fact that it was not written but, rather, committed to memory makes it no less literature despite the railings of many academics in universities who purport otherwise. Without the key to this world, the language, I often wonder from what standpoint they make their 'learned' assumptions.

I remember during my time at The University of Waikato when we were attempting to introduce Māori at MA level the opposition voiced by the teachers of the European languages, French in particular, because, by their definition, there was no literature. If Ngā Mōteatea, that four-volume collection of some of the finest pieces of Māori poetry, does not qualify to be called literature then I do not know what does! Add to that the collection of writings held by the National Library, the once former Alexander Turnbull collection, and one has more than sufficient material available for study and research at an advanced level.

The body of writing and language is being added to constantly with new compositions in haka, waiata, waiata-āringa and poi as well as collections of short stories, the odd novel and play, and articles on various topics. Like any collection of writings some of it is very good, some indifferent and some quite mediocre, but literature there indeed is!

Te kete aroiti, on the other hand, looks at those things not considered to be of any great import and therefore given scant regard, hence the term aroiti. This kete will have in it tolerance, compromise, mutual respect, acceptance of difference culturally, socially and linguistically, with the acceptance that difference is not necessarily divisive but conducive to the creation of a more interesting human mosaic. This kete, in my opinion, is a kete of some considerable importance with language, and attitudes to language, one of its principal foci.

Our history is one of internecine conflict and then conflict against the Pākehā, particularly, as our ancestors began to appreciate the full impact of the colonising of this country by a technologically and numerically superior culture. There was much that was positive and much that was negative as a result of that colonisation. 
The late Professor Quentin-Baxter stated in an article written by him for the New Zealand Law Journal:

If New Zealand has a destiny as a separate nation, rather than as a detached part of Australia, it will be principally because these islands were a meeting place of two great races and because - even in the worst of times - their dealings with each other never lacked a certain grandeur. It is of course a flawed record; but the world has no better record and can ill afford to lose this one. In return the theory and practice of the modern international law of human rights can reinforce our resolution to do whatever may be needed to reduce and to, finally, eliminate margins of disadvantage suffered by the Māori ... people in health, in education and in professional and other attainments. In richness of culture they will have the advantage, but it will be a shared advantage for Māori cultural tradition has never been exclusive. When the first European settlers came to New Zealand they brought with them everything except the stratified class society of England and Europe. The characteristic New Zealand demand, now taken up by the Māori was always for fairness and equality of opportunity - an affirmation of the intrinsic worth of every human being, found also in the Universal Declaration of Human Rights.

These sentiments, so eloquently expressed by the late Professor Quentin-Baxter, I never tire of quoting because I hold them to be substantially true although, over the years, the horizon once so promising of a beautiful new dawn has become quite heavily clouded. So what is actually needed for there to be a beautiful new dawn?

It is ironic to think that though we have bedded each other for well over two hundred years, bed being regarded by many as the panacea for all problems, the relationship is still shaky. There are, probably, no Māori in this country who do not have a non-Māori antecedent somewhere in the family whakapapa and one would have thought, obviously very naively, that that would have made a difference but, sadly, such is not the case.

Introduce the whole issue of language into the equation and the relationship becomes shakier still. Why do monolingual speakers of English of British descent have this strong desire to assert themselves linguistically and to take little, if any, cognisance of the language rights of others? We need only look at the fate of Gaelic, Irish and Erse to see how ruthlessly assertive English speakers were, and still are. The 
Welsh have weathered the storm comparatively better because they refused to succumb.

This attitude of linguistic annihilation and decimation survives and thrives here in Aotearoa/New Zealand and is probably one of the more unhealthy aspects of this country. It is a linguistic arrogance that is not to be tolerated, and certainly the whole of the Māori language movement is stating its opposition loudly and clearly.

While Māori is the language of the Māori it is an essential feature of the landscape of Aotearoa/New Zealand and is what makes this country unique in the world. Should the fate of the language be like that of the moa then the linguistic landscape of this country would have lost something of intrinsic value and, as a consequence, will, in my very humble opinion, be a less interesting place. It is the duty of all who claim to be of this place to ensure that the language survives for, as the Sicilian poet, Ignazzio Buttita, states in his rather moving poem:

Put a people in chains,

strip them,

plug up their mouths,

they are still free.

Take away their job,

their passport,

the table they eat on

the bed they sleep in,

they are still rich.

\author{
A people \\ becomes poor and enslaved \\ when they are robbed of the tongue \\ left them by their ancestors: \\ they are lost forever.
}

Despite all the Strum and Drang, these are exciting times here in Aotearoa/New Zealand, long considered a country of linguistic philistines with vowels so impure and diphthongised that they grated on the ear of those who preferred the clipped, precise language of Oxbridge and the BBC.

At long last we are not apologising for our accent, our brand of English, our modes of expression and our quite unique and interesting turns of phrase, much to the chagrin of the language purists and grammarians. Language survives 
because it is spoken, because it absorbs, because its domains increase and because its pool of speakers continues to increase.

Those last remarks are very pertinent to the Māori language situation. This generation of Māori speaks Māori far more frequently and openly than the preceding two generations and makes no apology for doing so. As Bob Dylan would have it, 'the times they are a-changin.'

In his book Language in Competition Ronald Wardhaugh states:

While some languages prosper others decline and fall. The signs of such decline and fall are many. A declining language loses its territorial base and is spoken by fewer and fewer monolinguals. Those who speak it become bilingual, finding that they must acquire the language that is beginning to dominate. The bilingual population becomes an increasingly aging population. The dominant language intrudes into more and more domains of life and assumes more and more functions. The dominated language is less and less used and is finally threatened as the language of the home itself. Diglossia may prevail for a time with each language having clearly marked domains of usage but, unless that diglossia is stable, the dominant language will continue its advance.

It is this situation which we are trying to decelerate and to arrest, our inspiration coming from the proverb he iti te mokoroa nāna i kakati te kahikatea' (the tallest tree in the forest can be felled by the smallest caterpillar). In other words, every effort made will further postpone the eventuality and, hopefully, dispel it for all time.

It is difficult to believe that it is only a little over thirty years ago that the Māori world came to the realisation that there was a need for the language to be retained, sustained and maintained. Rather than being the initiative of the educated middle class, it was the elders from all tribes throughout the country who set the linguistic ball in motion, with the cudgels being taken up on behalf of the language and culture by the young educated and politically astute Māori of the time. The movement owes much to this generation, the vast majority of whom had no language and were culturally deracinated.

The period of euphoria is over. It is now the time of 'solid slog', commitment to the proposition that this language is to be handed on to generations as yet unborn. No commitment 
means plainly and simply no survival, and one need not be an Einstein to come to that conclusion. We delude ourselves if we think all is well with the language and that its future is assured because the statistics have given us some number like 160,000 or so speakers. But what is the calibre of that language? What are its domains? Is it formal, rote learned language or language that is very informal yet Māori in ethos?

We must avoid, at all costs, or to the best of our ability, Māori that is Māori in word only but English in structure. It is already happening with expressions like 'tamaiti tawhito', 'kia pai tō rā', 'anō hoki me pēnei te mahi', 'me hoki he pai ki ahau' and so the nauseating list goes on. Many of the people interviewed by Te Karere fall into this category and so I wonder what benefits accrue to the language. Add to this the rather strong influence of English on the pronunciation that many of these second language learners have, and one is plunged further into the depths of gloom!

I am reminded here of an incident in Tahiti when I was there to attend one of the meetings of The Polynesian Languages Forum. I was travelling in a car with Maco Tevane, our Tahitian host, and the radio in the car was tuned to a Tahitian language radio station. I commented on how impressed I was to hear so much Tahitian being spoken since it was not readily heard in and around Papeete, the capital. Maco peremptorily dismissed the station, saying that it was actually French with Tahitian words, in other words, the intonation was French, the ethos was French and French heavily influenced the structure of the language. Mon Dieu, quelle horreur!

In our lamenting of our current state of language it is easy, with the benefit of hindsight, to point the finger at our parents, the education system, the unsympathetic and prejudiced Pākehā but, in the final analysis, the decision to speak or not to speak Māori is ours - each of us individually. The greatest enemy that our language has is our own inertia and our own apathy and anyone who says otherwise is merely searching for a scapegoat for his or her own lack of action.

It never ceases to amaze me that haka groups are prepared to devote the inordinate amounts of time that they do to the perfecting of their performances. And yet the language that is absolutely essential to the performing arts receives scant attention, that attitude being reflected in the poor and often incorrect lyrics that some groups persist in singing. 
It is fine to perfect one's singing, one's twirling of the poi, and one's performance in the haka and yet the same attention and devotion are not devoted to the language. The prevailing attitude would appear to be near enough is good enough for the language but not for the performing arts! Why?

The whole syndrome of 'near enough is good enough' was never part of the thinking of our tipuna. Tribal reputations rose or fell depending on the linguistic skills of the orators, the karanga women, the singers and the lavishness with which hospitality was offered. Only the best was acceptable so only the best orators spoke, only the best karanga women would karanga, only the best of food and hospitality were extended to the guests, even if the host tribe starved for some time after the guests had departed. Guests, in turn, would honour their hosts by bringing their best orators, karanga women and singers, and the gifts offered to the hosts in appreciation of their hospitality had to be the best.

When one looks at the world of Māori art and craft then and now, one is impressed and full of admiration for the excellence of the craft displayed, from the beautifully carved houses to the tukutuku, kōwhaiwhai and whāriki within them, the vast array of kete and the materials employed to weave them, piupiu, the very many beautiful cloaks produced by the nimble fingers of women such as the late Dr Rangimārie Hetet. To achieve this incredible degree of beauty in the weaving and carving arts, an apprenticeship has to be served, quite often spanning many years. Such excellence does not come easily.

And so it is with the language. One cannot hope to scale the linguistic heights, to master the subtleties and nuances of the language, its rhythms, colloquialisms and idioms, its metaphors, its aphorisms and all those other aspects of language without first mastering the elementary aspects and knowing how it operates.

What I am trying to say here is that if the same amount of time devoted to the dance arts were devoted to the language then one would have a passable command in a comparatively short time. But, and this is a big BUT, the exemplars must be just that, exemplary; just as a haka group must have a knowledgeable tutor, so does the student of language.

If one is a speaker then speak Māori i ngā wāhi katoa, i ngā wā katoa (in all places, at all times). If one has no language, but would like to acquire it, then approach an appropriate institution or person and start learning. If one wishes to do neither, then so be it, but do not berate and 
excoriate those who do, or expect them to compromise their language stand because you have done nothing about your own. Make way and let us move on.

Rhetoric will do little to sustain language growth, but commitment will do much to ensure language survival so that we are not posed the following question, as mentioned in a waiata-ā-ringa, by generations yet to be born, 'I ahatia e koe taku taonga e?' (What have you done with my heritage?)

When Māori was declared an official language of this country on 1 August 1987 it was a red letter day for us and for those non-Māori who care for the language and its survival, while it proved to be an irritant to those who opposed any such legislation, manifesting that opposition in anonymous vitriolic letters to me, the then Māori Language Commissioner, and my staff of the time. Time has seen a marked change in attitude, but there will always be the vociferous dissenters, just as there will always be the vociferous proponents.

For some reason Māori is considered to be the language that divides and English the language that unites. A single language, clearly, is not the solution, as stated by Tāmati Reedy, Dean of the School of Māori and Pacific Development at the University of Waikato, in evidence submitted to The Waitangi Tribunal when the whole issue of declaring Māori an official language of Aotearoa was being heard in 1986. He stated on that occasion:

A few short years ago prominent linguists were predicting that Māori would decline to the extent that it would be used only on ceremonial occasions. However, Māori people have not accepted that fate for their language.

The history of New Zealand is testimony to the fact that language is both divisive and unifying. The British colonists have always seen English as the language for unifying Māori and Pākehā and Māori the language that kept the two people apart. The unifying force of Māori among the Māori - or for the nation - was seen as neither desirable nor necessary and consequently all past policies have forcibly or tacitly been directed at its demise. The devastating effects of language loss are reflected throughout Māoridom today - grasping for an identity through language. Compounded by the efforts of low socio-economic status, continuing under-achievement, unemployment, high criminal youth offending, the sense of being 'Māori' for most New Zealanders is completely negative.

The fact that English is now the only working language for the vast bulk of Mãoridom has not brought about the social 
unity promised by the anti-Māori language policies of the past 150 years.

Māoridom today appears to be more bent on remaining Māori despite the poor self-image that post European history has bestowed on the label 'Māori'. Clearly, Māori language is being seen by many as the rallying point for a restructuring and piecing together of a much broken and damaged people.

It serves to restore an identity for people who see themselves as Māori and want to be recognised as such.

Tāmati Reedy is not alone in his contention, as exemplified by this statement by Ayo Bamgbose, formerly Professor of Linguistics at the University of Ibadan, Nigeria, in an article in the UNESCO Courier of February 1994:

A complementary myth to that of divisiveness is the myth that a single language can unite. In Nigeria, the English language, which was the official language in the colonial period, is widely considered the best candidate for a unifying role. It is well-entrenched, having been used as the language of government and education thereby 'uniting' elites from the different ethnic groups. Furthermore, because it does not belong to any ethnic group in Nigeria it is believed to be a 'neutral' language. However, a common language does not automatically induce unity unless there are already unityinducing factors in the communities concerned, and it is simply not true that a language can be neutral since it inevitably comes with the baggage of the culture it represents.

Peter Muhlhauser, Foundation Professor of Linguistics at the University of Adelaide, Australia, had this to say in the same publication as that of the foregoing remarks:

Linguistic diversity is a resource whose value has been widely underestimated. If we regard each language as the result of a long history of human endeavour to gain knowledge of the world, we may begin to see why linguistic diversity is an invaluable resource rather than an obstacle to progress.

A Japanese gentleman put it more succinctly when he observed, 'To know one language is to know only one universe.'

Need one say more about the whole issue of one language?

Ignorant critics say that Māori is a stone-age language and only capable of stone-age concepts. All linguists accept that borrowing is valid behaviour for any language. For some reason when Māori borrows from English, or wherever, as it did upon initial contact and still does on occasion today, that 
is seen as not being quite acceptable. English, on the other hand survives, and is the rich language that it is because of its shamelessly voracious appetite for borrowing. Ah me those who dwell in glass houses!

Many people who oppose government intervention in the revival and survival of the Māori language state that it is a Māori responsibility first and foremost and I have little argument with that philosophy, up to a point. Tāmati Reedy stated that many of the policies of government were not conducive to the survival of the language nor was the attitude of some of our elders when they urged us to get an 'education'. To be 'educated', by their definition, meant the abandonment of our own language and customs and the adopting of that of the colonising powers as though that were the panacea to the Māori problem. I criticise here from the advantage of hindsight and wonder whether I would have been any different in my encouragement to Māori youth were I in the position of my elders?

There comes a time when the finger pointing and blame sought elsewhere must cease for excusing inaction in the here and now. Wharehuia Milroy has this sage advice to offer in one of his many compositions:

Kāti tā tātou tangi ki a rātau kua riro ki te pō

Tēnā tātau ka tahuri ki te kumanu i te reo

Kia tū tonu ai te whare kōrero hei whare tāwharau

Mō te reo ki te ake, ake rawa

Arā kia mau te rongomaiwhiti o te reo nei

Hei moko mō te tuakiri o ngā tātai o āpōpō

Kia ngunguru ai te reo $i$ te ao, $i$ te pō

(Let us cease lamenting that which is past

But rather let us set about carefully tending to our language

So that the nidus remains as a place of refuge

For the language for all time

That the unique nature of the language is retained

As an icon of identity for tomorrow's generations

And so that the language will resound day and night)

Those entrusted with the education of the Māori were very racist in their attitude, as exemplified by the following remarks made by a school inspector called Henry Taylor in 1862 when he said: 
I do not advocate for the Natives under present circumstances a refined education or high mental culture; it would be inconsistent if we take account of the position they are likely to hold for many years to come in the social scale and inappropriate if we remember that they are better calculated by nature to get their living by manual than by mental labour.

Another inspector, William Bird, expressed the view that teachers who had ceased using Māori in their classes were to be commended and that Māori children should be encouraged 'to speak only English in the playground'.

Add to the attitude exemplified in the forgoing paragraph the fact that English was the medium of instruction when the vast majority of Māori students up until well after World War II were predominantly Māori speaking, particularly in the rural areas.

Now what does that say about enlightened attitudes to education, to amour propre, to human dignity?

My own whāngai mother, Mauwhare Kāretu, was, at 16, still in Standard Two and never spoke English because her command was very rudimentary and, if she could avoid doing so she would. My father, Tame Kāretu, went to Te Aute College where, in an endeavour to improve their command of English, they were permitted to speak Māori only on Wednesdays between the hours of 3-5 p.m. Unlike my mother, his command of English was quite good but he would lapse quite readily into Māori as soon as circumstances permitted.

In my mother's case it was not a question of intellect but one of language and yet the powers that be still insisted that the medium of instruction be English. My father managed to weather that storm but it does point up the iniquity of a system that was more punitive than educational.

It is very difficult for me to look at these instances without, at my most cynical, thinking that the Māori language was the sacrificial lamb on the fire of Pākehā education. The attitude prevalent at the time is incomprehensible when one considers that it was the so-called educated who were enforcing this state of affairs. The unhealthy desire to reduce everyone to a common denominator has to be firmly rooted from the human condition.

The late John Te Rangiāniwaniwa Rangihau once said, 'I never cease to be amazed at the Pākehā who knows better than I do what is good for me, the Māori'. This sentiment is 
amplified further in a haka composed in 1990 which has the following lines:

Nei tāku

Whakahokia mai taku mana

Mana motuhake, mana Māori

Māku anō au e kōrero!

Māku anō au e tohutohu!

Māku anō au e whakatika!

(Here is my opinion!

Restore my self-respect

My right to be different, my right to be Māori

I can speak for myself!

I can advise myself!

I can put my own house in order!)

Many Māori would say that the patronising attitude still prevails, but surely the role of education is to bring enlightenment to the masses, not to condemn them so that they 'get their living by manual labour' for the rest of their days? Surely that is the case?

It was Sir Apirana Ngata who advocated that to be successful we need to master 'the tools of the Pâkehā' in order to survive but never to abandon 'the treasures of your ancestors' for they should be 'as a diadem on your brow'. The advice is pragmatic, practical and easy to follow but reminds us that we need the best of both worlds, which is what I think Professor Quentin-Baxter was advocating, although not so overtly.

Perhaps my fourth kete now comes into its own. It will be apparent from what I have said thus far that the acceptance of our right to our place in the sun on our own terms is frowned upon by many of the majority culture. Is that, however, any reason for me not to persist, or to continue to resist the constant attempts by the majority culture to make me more like them and, for the vast majority of them, not to make any moves at all in my direction? I say, categorically, no, for as my ancestors would have it, e kore au e hoki noa i te waewae tūtuki, ka pā anō i te ūpoko pakaru (mere trifles will not deter me from my avowed intent, only a catastrophe of major proportions will do that).

Our continued adversarial, confrontational stance will only exacerbate, not ameliorate, the situation so a fourth kete, or basket of knowledge, is definitely needed, but to continue to 
call it te kete aroiti is to demean its importance. Only its contents, those of tolerance, compromise, mutual respect and acceptance of difference as not being divisive, will bring about the goodwill and accord that we all wish and hope for. With such a positive attitude how can the survival of our language, our culture and our identity not be guaranteed? 